\title{
Biomass to Bioethanol: Initiatives of the Future for Lignin
}

\author{
Nicolas Brosse, ${ }^{1}$ Mohamad Nasir Mohamad Ibrahim, ${ }^{2}$ and Afidah Abdul Rahim ${ }^{2}$ \\ ${ }^{1}$ Laboratoire d'Etude et de Recherche sur le Materiau Bois, Faculté des Sciences et Technologies, Nancy-Université, Bld des Aiguillettes, \\ 54500 Vandoeuvre-lès-Nancy, France \\ ${ }^{2}$ Lignocellulosic Research Group, School of Chemical Sciences, Universiti Sains Malaysia, 11800 Pulau Pinang, Malaysia
}

Correspondence should be addressed to Nicolas Brosse, nicolas.brosse@lermab.uhp-nancy.fr

Received 9 May 2011; Accepted 14 June 2011

Academic Editors: D.-p. Kamdem, H. Ku, and H. Yoshihara

Copyright () 2011 Nicolas Brosse et al. This is an open access article distributed under the Creative Commons Attribution License, which permits unrestricted use, distribution, and reproduction in any medium, provided the original work is properly cited.

Lignin, which is one of the most abundant natural materials, represents a vastly underutilized natural polymer. With the emerging necessity to develop alternative sustainable transportation fuels, bioethanol produced from lignocellulosic biomass is considered as a viable option to petroleum-derived fuels. The effective utilization of biomass feedstock necessitates the development of costeffective pretreatment technologies that are necessary to separate the three main biopolymers (cellulose, hemicellulose, and lignin). One of the key issues concerning the pretreatment process is the full recovery of the feedstock through optimum utilization of all lignocellulosic components, including nonsugar compounds, as marketable products. Thus, availability of high-quality lignin in large quantities should stimulate development in new lignin applications in the fields of fibres, biodegradable polymers, adhesives, and surface treatment (rust converter).

\section{Introduction}

The decreasing reserves of fossil fuels and the necessity to protect our environment have resulted in a great amount of research in the past couple of decades on renewable sources of liquid fuels to replace fossil fuels. One of the more promising alternative energy sources is ethanol produced through fermentation of sugars. Ethanol is currently used as a partial gasoline replacement. A potential source for future low-cost ethanol production is to utilize lignocellulosic materials such as crop residues, grasses, sawdust, wood chip, oil palm empty fruit bunch, trunk, and frond. Lignocellulosic feedstock is mainly composed of three biopolymers (i.e., cellulose, hemicellulose, and lignin), and its effective utilization necessitates the development of pretreatment technologies which are necessary to separate the polysaccharidic fractions and to enhance the enzyme digestibility of cellulose. Several types of physicchemical pretreatments for lignocellulosic biomass conversion have been proposed, including steam explosion, ammonia fiber explosion, and microwave digestion (for a recent review, see [1]). Chemical pretreatments that have been proposed include sulfuric acid, sulfur dioxide, organosolv, sodium hydroxide, and wet oxidation. These technologies have been evaluated and optimized for the delignification of hardwood [2], softwood [3, 4], dedicated energy crops $[5,6]$, agricultural wastes including corn cob $[7,8]$, sugar cane bagasse, rice husk [9], and grape stalks [10].

To improve the overall effectiveness of bioethanol production, one strategy is the biorefinery model in which all components of biomass are fully used to produce a wide range of value-added products [11]. Pretreatment processes which allow a clean fractionation of lignocellulosic feedstocks and the recovery of high-quality lignins are of great interest and are currently a focus of attention. Thus, availability of such lignin fractions in large quantities should stimulate development in new lignin utilizations. This paper presents the progress of various pretreatments of lignocellulosic biomass to produce high-quality lignins. Impacts of the process conditions on the chemical structure of the recovered lignin fractions and on delignification mechanisms are exposed, and recent utilizations of lignins for the production of green materials (e.g., biodegradable polymers, and adhesives) are given. 


\section{Pretreatment Processes for Bioethanol Production and Lignin Recovery}

The objective of the pretreatment is to alter the structure of biomass to make cellulose more accessible to the enzymes that convert the carbohydrate polymers into fermentable sugars. Lignin is the most recalcitrant component of the plant cell wall, and the main goal of pretreatment is not only to break the lignin seal but also to disrupt the crystalline structure of cellulose. In this paper, we will focus on the pretreatment technologies which extract and remove most of the lignin from the raw material. Production of lignin should be an advantage over alternative processes, and should stimulate development in new lignin applications and should give an added value to the process (Figure 1).

2.1. Steam Explosion [12-17]. In a steam explosion process, the biomass is treated with high-pressure saturated steam, eventually in the presence of a catalyst, at a temperature of $160-260^{\circ} \mathrm{C}$, and then the pressure is suddenly reduced, which makes the materials undergo an explosive decompression. The removal and redistribution of hemicellulose and lignin increase the volume of the pretreated sample which enhanced its cellulose digestibility. During this step, lignin is removed only to a limited extent but is redistributed on the fiber surfaces as a result of melting and depolymerization/repolymerization reactions. The lignin fragments can be further extracted using organic solvents or basic aqueous solution [3].

2.2. Organosolv Treatment $[5,18-21]$. Organosolv pretreatment of biomass resides on the use of an organic solvent system with enhanced solubilizing properties due to organic components. Alcohols are the most frequently used solvents in organosolv pretreatments, and, due to its low cost, ease of recovery, and low toxicity, ethanol is the most favored alcohol. Biomass is treated with the addition of a catalyst at low temperatures (below $180^{\circ} \mathrm{C}$ ) or without a catalyst (autocatalysis) at higher temperatures $\left(185-210^{\circ} \mathrm{C}\right)$. The catalyst generally employed is sulphuric acid. After cooking, the solid residue (pulp) is filtered and washed with an ethanol solution. The resulting black liquor is diluted with water to precipitate the organosolv lignin.

2.3. Alkaline Pulping Processes [22-28]. Alkaline pulping processes such as kraft pulping and soda pulping are known as potential pulping processes for nonwoody materials. Essentially, both processes function to liberate lignin, hemicelluloses and cellulose to enhance the quality of the pulp. In some cases, the addition of oxygen or hydrogen peroxide to the reaction mixture greatly improves the delignification of the biomass especially for wood-related bioresources [29, 30]. Kraft pulping is a dominant pulping process in the world. This process enables pulping of different tree species, recovers and reuses all pulping chemicals, and produces a high-quality paper. However, there is a growing interest in applying soda pulping for nonwoody material in papermaking such as oil palm empty fruit bunch fiber (EFB).

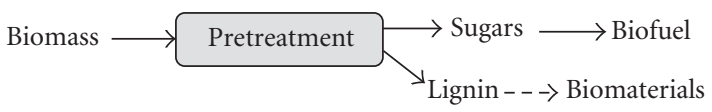

FIGURE 1: Schematic of the conversion of lignocellulosic biomass to biofuel and biomaterials.

Fibrous derivates from EFB, however, represent a renewable source of nonwood lignocellulosic materials which has created considerable research interest, not only in the pulp and paper industry but also in the composite industry. The process of producing cellulosic pulp from oil palm trunk fiber and other nonwood fibers requires delignification with sodium hydroxide under pressure. This liberates the cellulosic fiber and produces a large quantity of black liquor. The pulp and paper industry normally burn the lignin dissolved in the black liquor for energy generation. However, the lignin, which has been separated from hemicelluloses and cellulose during the pulping process, can be utilized as a starting material, due to its variable functional groups; these functional groups could lead to tremendous potential reactive sites for chemical and biochemical modification.

Both pulping processes (kraft and soda) were carried out in a digester. For kraft pulping, a 19\% active alkali and a $25 \%$ sulphidity with water to solid ratio of 8 was used. The digester was heated from room temperature to $170^{\circ} \mathrm{C}$ for one hour and continued at $170^{\circ} \mathrm{C}$ for 2 hours. The contents in the digester were stirred by rotating the digester via a motor. For soda pulping, 25\% active alkali with no percentage of sulphidity was applied and the same condition was used. After cooking, the pulp and black liquor were mixed. The pulp was washed and separated by screening through a sieve, and the black liquor was collected. Lignin was precipitated from the concentrated black liquor by acidifying it until $\mathrm{pH} 2$ using 20\% (v/v) sulphuric acid. The precipitated lignins were filtered and washed with $\mathrm{pH} 2$ water. Both lignins were then dried in an oven at $45^{\circ} \mathrm{C}$ for 48 hours.

Aqueous ammonia in a flow through mode known as ammonia recycled percolation (ARP) process has also been described [31]. At the end of the reaction, lignin can be precipitated from the black liquor by acidification.

\section{Structural Aspects of Lignin}

3.1. Native Lignin. Lignin is biosynthesized from three monolignols: $p$-coumaryl, coniferyl, and sinapyl alcohols which give rise, respectively, to the so-called $p$-hydroxyphenyl $(\mathrm{H})$, guaiacyl $(G)$, and syringyl (S) phenylpropanoid units. $H$, $\mathrm{G}$, and $\mathrm{S}$ units show different abundances in lignins from different groups of vascular plants, as well as in different plant tissues and cell-wall layers. During biosynthesis, the monolignols undergo an in situ radical polymerization, yielding several interunit linkages including aryl ether $(\alpha-$ $\mathrm{O}-4^{\prime}$ and $\left.\beta-\mathrm{O}-4^{\prime}\right)$, resinol $\left(\beta-\beta^{\prime}\right)$, phenylcoumaran $\left(\beta-5^{\prime}\right)$, biphenyl $\left(5-5^{\prime}\right)$, and 1,2-diaryl propane $\left(\beta-1^{\prime}\right)$ as depicted in Figure 2 [32].

In the past decades, lignin was described as an extremely complex three-dimensional, amorphous, cross-linked, and 
<smiles>[R]c1cc(/C=C/CO)cc([R])c1O</smiles>

$\mathrm{R}^{1}=\mathrm{R}^{2}=\mathrm{H}$ : $p$-coumaryl alcohol, hydroxyphenyl $(\mathrm{H})$

$\mathrm{R}^{1}=\mathrm{OMe} ; \mathrm{R}^{2}=\mathrm{H}$ : coniferyl alcohol, guaiacyl $(\mathrm{G})$

$\mathrm{R}^{1}=\mathrm{R}^{2}=$ OMe: sinapyl alcohol, syringyl (S)<smiles>COc1ccc(CC(C)Oc2ccccc2)cc1</smiles>

$\beta-\mathrm{O}-4^{\prime}$<smiles>COc1ccc(C2Oc3ccccc3C2C)cc1</smiles>

$\beta-5^{\prime}$<smiles>CCC(Oc1ccccc1)c1ccc(OC)cc1</smiles>

$\alpha-\mathrm{O}-4^{\prime}$<smiles>C=CCc1ccc(OC)c(-c2cc(CCC)ccc2OC)c1</smiles>

$5-5^{\prime}$<smiles>COc1ccc(CC(C)CC(C)Cc2ccc(OC)cc2)cc1</smiles>

$\beta-\beta^{\prime}$

Figure 2: Building blocks of lignin and common linkages between phenyl propane units.<smiles>C/C=C(/C=C/C)C(O)C(CO)Oc1ccc(C(O)C(CO)Oc2ccc(C(O)C(CO)Oc3c(OC)cc(C4OCC5C(c6cc(OC)c(OC(CO)C(O)c7ccc(OC(CO)C(O)c8cc(OC)c(O)c(OC)c8)c(OC)c7)c(OC)c6)OCC45)cc3OC)cc2OC)cc1OC</smiles><smiles>CCC(O)C(COC(=O)c1ccc(O)cc1)C(O)c1c(OC)cccc1OC</smiles><smiles>COCC(Oc1ccc(C(O)C(CO)Oc2ccccc2OC)cc1OC)C(O)c1cc(OC)c2c(c1)C(CO)C(c1cc(OC)c(O)c(OC)c1)O2</smiles>

Figure 3: Lignin polymer model for lignins from poplar.

three-dimensional phenolic polymer resulting from random polymerization processes. Recent papers seem to demonstrate that the structure of native lignin is mostly linear and composed of repetitive units involving mainly $\beta-O-4^{\prime}$ interunit linkages $[33,34]$ as depicted in Figure 3 [33].

3.2. Organosolv Pulping. In organosolv pulping using an acidic catalyst, the cleavage of the ether linkage is primarily responsible for lignin depolymerization processes. According to several authors, the acidic hydrolysis mainly affected the $\mathrm{C} \alpha$ position of the side chains $[35,36]$. The solvolytic splitting of $\alpha$-aryl ether (or $\alpha$-sugar) leads to the formation of a benzylic carbocation which can react with the solvent (Figure 4). In high severity reaction conditions, extensive aryl-ether bond hydrolysis and $\beta$-ether cleavages through the formation of Hibbert's ketones [37] were observed. In the range of experimental conditions generally employed in the literature, organosolv process produced a relatively pure, unaltered, and high-quality lignin of low molecular mass bearing high phenolic and aliphatic hydroxyl contents.

3.3. Soda Pulping. In alkaline processes, ionization of a free phenolic $\mathrm{OH}$ group at the $\mathrm{C} 4$ position facilitates the formation of a quinone intermediate accompanied with the 

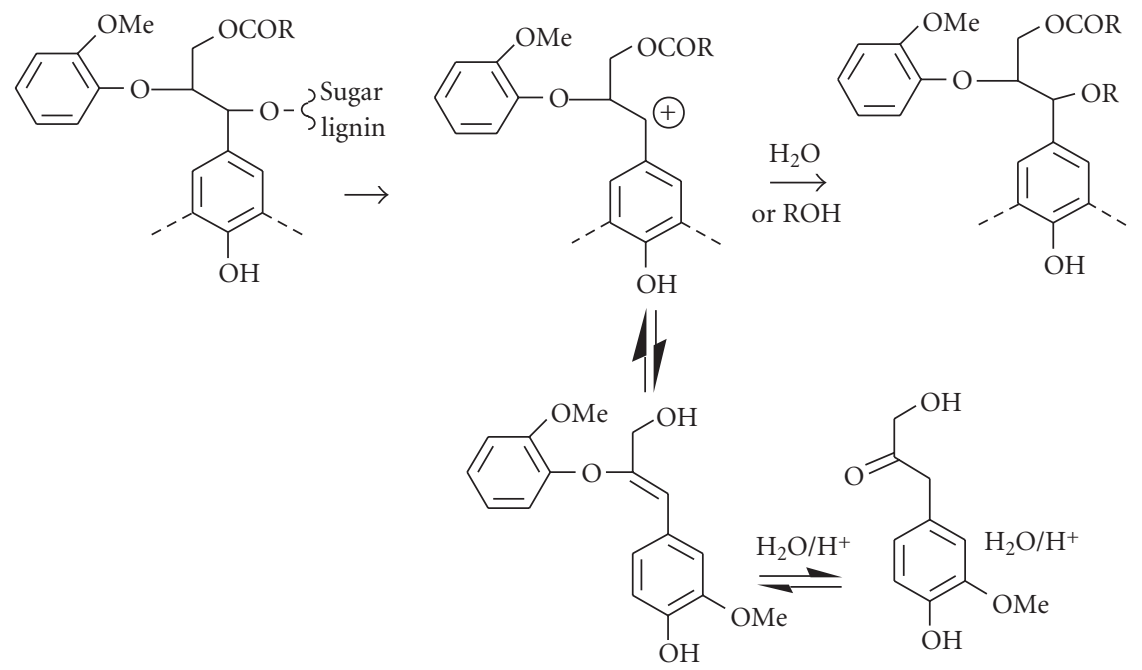

FIgURE 4: Mechanism of acidic solvolytic cleavage of aryl ether linkages.

elimination of the group at the $\alpha$ position. $\beta$-ethers can be cleaved according to Figure 5: An ionized hydroxyl group serves as a nucleophile in displacing the neighboring aryloxy group.

3.4. Steam Explosion. In a steam explosion process, homolytic cleavage was described with the formation of an intermediate quinine methide which degrades to give stilbenes through the loss of the $\gamma$-methylol group as formaldehyde. Such mechanism and structures were previously identified in kraft pulping [38] and also during the ethanol organosolv treatment as shown in Figure 6 [39].

\section{Current and Future Utilizations of Lignin for Material Applications}

4.1. Polymer Blends. The development of biodegradable materials and/or materials from renewable sources, such as polyesters, polylactides, and polysaccharides, is in great demand, but such polymers show, in general, poor mechanical, thermal properties and prohibitive cost which prevent their large commercial utilization. As a result of these limitations, research efforts have concentrated to modify these polymers by producing biodegradable polymers by bending with lignins. The thermal properties and miscibility of poly(hydroxybutyrate) (PHB) and soda lignin blends were recently investigated by Mousavioun et al. [40] using thermogravimetry analysis, differential scanning calorimetry, scanning electron microscopy, and Fourier transform infrared spectroscopy. The results suggested compatibility for the blends containing up to $40 \mathrm{wt} \%$ soda lignin. The infrared data show that the miscibility of the blends is associated with specific hydrogen bonding interactions between the reactive functional groups in lignin with the carbonyl groups of PHB (Figure 7).
Blends of steam-explosion lignin and poly( $\varepsilon$-caprolactone) (PCL) were prepared with the technique of highenergy ball milling [41]. It was shown that the addition of lignin stabilized the PCL against UV radiation and increased the modulus of the blends. Nevertheless, the presence of lignin decreased the tensile strength and the elongation at break because of the poor compatibility between lignin and the synthetic polymer.

In polymer blends, lignin can be used to diminish the effect of chemical stress by inhibiting atmospheric degradation, acting as an antioxidant, and ultraviolet light stabilizer. Feldman et al. [42] described the blends obtained from an unplasticized poly(vinyl chloride) (PVC) compound, formulated with organosolv lignin. The objective of this study was the development of new vinyl flooring formulations with increased resistance to attack by fungi and microorganisms. The results indicated that lignin could replace up to 20 parts of the copolymer. At this level of replacement, the key mechanical properties of the new composites compared very favorably with those of the control formulations. The results obtained suggested a proton donor/proton acceptor interaction between lignin and PVC chains.

Alcell lignin was thermally blended with poly(ethylene oxide) (PEO) over a range of blend compositions, and good spinning properties were observed [43]. Compared with kraft lignins, Alcell lignin displayed better plastic behavior and the corresponding PEO blends were described to possess good thermoforming properties.

Thus, because of the presence of polar groups (phenols and alcohols), lignin can show a good affinity toward synthetic polymers bearing functional groups like polyesters, polyethyleneoxide, or polyvinylchloride. On the other hand, the mechanical properties of lignin-based hydrophobic polymer blends were poor because of phase separations due to a lack of compatibility. To circumvent this limitation, many derivatization reactions have been carried out and among them, etherification of lignin with alkylene oxides (especially 


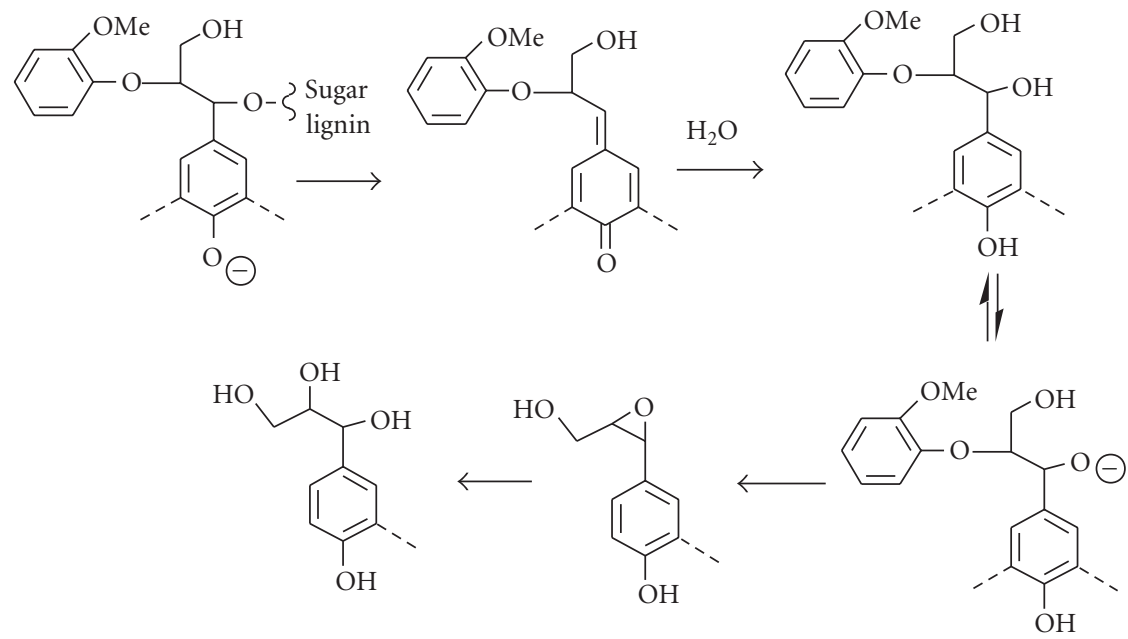

FIGURE 5: Mechanism of the solvolytic cleavage of aryl ether linkages in basic medium.<smiles>[R]c1ccc(OC(CO)C(O)c2ccc(O)c(OC)c2)c(OC)c1</smiles><smiles>[R]c1ccc(OC(C=C2C=CC(=O)C(OC)=C2)CO)c(OC)c1</smiles><smiles>[R]c1ccc(OCCCO)c(OC)c1</smiles><smiles>[R]Oc1cc(C(O)C(CO)c2ccc(C)c(C)c2)ccc1O</smiles><smiles>COc1cc(/C=C/c2ccc(I)c(C)c2)ccc1O</smiles>

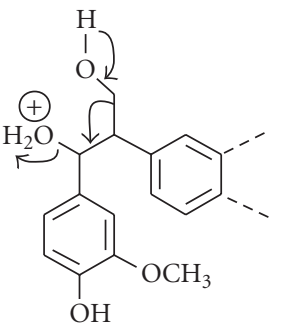

FIGURE 6: Degradation mechanism of $\beta$-aryl ether during a steam explosion process.

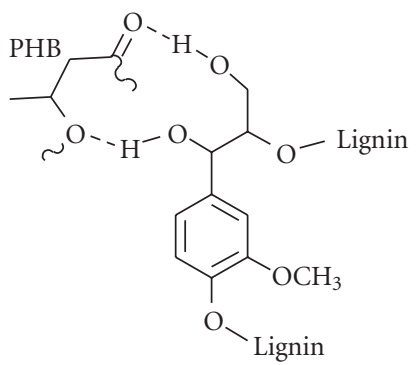

FIgURE 7: Hydrogen bonding interactions between the reactive functional groups in soda lignin and the carbonyl groups of PHB.

ethylene oxide) has been extensively studied [44]. This chemical modification is carried out in aqueous alkali at room temperature and produces unifunctional derivatives with only aliphatic hydroxy groups $[45,46]$. A drastic reduction of glass transition temperature was observed accompanied by an enhanced solubility in organic solvents. Thus, a decrease in brittleness could be achieved in the resulting material through the introduction of soft molecular segments capable of a plastic response to mechanical deformation. The esterification of soda lignin was also studied in order to increase its hydrophobicity for utilization as a lubricant for thermoplastics or for composite applications.

4.2. Environmentally Friendly Wood Adhesive. With an increasing pressure from environmentalists as well as an increasing in general public knowledge towards safe environment, manufacturers are left with little alternatives except to produce more environmentally friendly products from their 
factories. This is also true in the wood processing industries where the uses of adhesives are very extensive.

Adhesives are required in many wood processing industries such as particleboard, wood panels, fibre board, and plywood. Among the various adhesives used for the production of these articles, phenol formaldehyde (PF) resin is the most common type of adhesive [47]. With the increasing use of composite materials such as strand board, flake board, and composite lumber, the demand for adhesive is increasing. These adhesives are in adequately supply today, but the scarcity of petroleum products could affect the future cost and availability of these petroleum-based adhesives [47].

Lignin-phenol-formaldehyde (LPF) resin was prepared in two stages. The first stage involved the preparation of lignin-phenol adduct (LP), while the second step comprised the preparation of lignin-phenol-formaldehyde resin. In the first stage, $28.0 \mathrm{~g}$ of dry lignin and $28.0 \mathrm{~g}$ of phenol were mixed in a beaker. The mixture was stirred at $40^{\circ} \mathrm{C}$ for one hour to obtain a homogenous mass of lignin-phenol adduct. In the second stage, $23.28 \mathrm{~g}$ of LP adduct, $20.27 \mathrm{~g}$ of formaldehyde solution, $10 \mathrm{~g}$ of methanol, and excessive phenol (in order to obtain the desired phenol: lignin ratio) were mixed in a three-neck round-bottom flask and heated. The objective of this study was to replace as much phenol as possible with lignin. When the temperature attained $80^{\circ} \mathrm{C}$, $1.16 \mathrm{~g}$ of sodium hydroxide which was dissolved in $10 \mathrm{~g}$ of distilled water was added to the mixture. The heating process was allowed to continue for 4 hours [48]. From this study, the maximum lignin to phenol ratio was found to be $30 \%$.

Fourier Transfer Infrared spectrometry (FT-IR) was used to analyze functional groups present in both the LPF and CPF resins. Apart from this, all samples underwent the close contact joint or adhesive tensile strength tests in accordance with ASTM D897 specifications [49]. The same procedures were used to compare the adhesive strength of LPF resin with CPF resin. Wood samples measuring $100 \mathrm{~mm}$ $\times 25 \mathrm{~mm} \times 10 \mathrm{~mm}$ were used as substrates for tensile testing. During the procedure, adhesive was applied on both sides of interface within a $50 \mathrm{~mm} \times 25 \mathrm{~mm}$ area. The glued samples were pressed in a hot pressing machine at $160^{\circ} \mathrm{C}$ for 20 minutes. Subsequently, the tensile strength of the samples was analyzed at a crosshead speed of $6 \mathrm{~mm} / \mathrm{min}$.

Finally, a capillary viscometer with three tubes, that is, capillary tube, venting tube, and filling tube, was used to measure the viscosity of the resins. The procedure involved channeling the resin into the filling tube and allowing it to flow down to the bottom of the viscometer. The resin was then sucked up through the capillary tube by applying vacuum pressure at the venting tube. The duration taken for the sample to fall down to the bottom of the capillary tube was recorded after the suctioning process was stopped. The viscosity of both resins was determined on the seventh day of every week over a 3 -week period. Figure 8 depicts the infrared (IR) spectra of the lignin-phenol adduct and LPF and CPF resins. The absorption bands in the $3300 \mathrm{~cm}^{-1}$ region for lignin-phenol adduct and LPF and CPF resins reveal the presence of the $\mathrm{OH}$ functional group. In addition, the stretching vibrations of the aromatic compound for the lignin-phenol adduct and the LPF and CPF resins are
TABLE 1: Tensile strength test using LPF resin as an adhesive.

\begin{tabular}{lccc}
\hline Samples & $\begin{array}{c}\text { Maximum load } \\
(N)\end{array}$ & $\begin{array}{c}\text { Ultimate tensile } \\
\text { strength }(\mathrm{MPa})\end{array}$ & $\begin{array}{c}\text { Elongation at } \\
\text { break }(\%)\end{array}$ \\
\hline 1 & 3823.50 & 15.39 & 1.84 \\
2 & 2944.85 & 11.78 & 1.32 \\
3 & 1866.08 & 7.51 & 0.33 \\
\hline Mean & 2878.14 & 11.56 & 1.163 \\
\hline
\end{tabular}

TABLE 2: Tensile strength test using CPF resin as an adhesive.

\begin{tabular}{lccc}
\hline Samples & $\begin{array}{c}\text { Maximum load } \\
(N)\end{array}$ & $\begin{array}{c}\text { Ultimate tensile } \\
\text { strength }(\mathrm{MPa})\end{array}$ & $\begin{array}{c}\text { Tensile stress } \\
(\%)\end{array}$ \\
\hline 1 & 2536.78 & 5.15 & 0.53 \\
2 & 2269.43 & 4.55 & 1.45 \\
3 & 2930.61 & 7.15 & 2.28 \\
\hline Mean & 2578.94 & 5.61 & 1.42 \\
\hline
\end{tabular}

discernible within an adsorption band in the $1600 \mathrm{~cm}^{-1}$ to $1500 \mathrm{~cm}^{-1}$ region.

The bending vibrations of a $\mathrm{C}-\mathrm{H}$ asymmetry from methyl of aromatic group for CPF and LPF are, respectively, at the $1461 \mathrm{~cm}^{-1}$ and $1472 \mathrm{~cm}^{-1}$. The frequencies $1273 \mathrm{~cm}^{-1}$ for CPF and $1233 \mathrm{~cm}^{-1}$ for LPF indicate asymmetric stretching for phenolic $\mathrm{C}-\mathrm{C}-\mathrm{OH}$. Besides this, the peak frequency of $1144 \mathrm{~cm}^{-1}$ for $\mathrm{CPF}$ is indicative of a $\mathrm{C}-\mathrm{O}$ stretching vibration, while the peak of frequency $1115 \mathrm{~cm}^{-1}$ shows the presence of ether aliphatic through asymmetric stretching vibration for $\mathrm{C}-\mathrm{O}-\mathrm{C}[50]$.

Both the lignin-phenol adduct and the LPF resin have similar peaks at band $1470 \mathrm{~cm}^{-1}$ indicating the presence of a methylene bridge [51]. However, this band is not present in the CPF resin. Furthermore, two bands at 2900 and $2800 \mathrm{~cm}^{-1}$ in the lignin-phenol adduct and LPF spectra signify the presence of $\mathrm{CH}$ stretching. Finally, the confirmed presence of lignin in both the lignin-phenol adduct and LFP compounds is indicated by the $\mathrm{CH}$ stretching in syringyl and the presence of $\mathrm{C}-\mathrm{O}$ primary alcohol at bands 1113 and $1115 \mathrm{~cm}^{-1}$, respectively [51].

The tensile strength results for both CPF and LPF adhesive bonds were analysed in order to measure the bonding strength between the adhesive and the wood substrate. Tables 1 and 2 show the results of the ultimate tensile strengths tests for LPF and CPF, respectively. The mean value recorded was $11.56 \mathrm{MPa}$ for LPF and $5.61 \mathrm{MPa}$ for CPF. The results indicate that the adhesive strength of LPF on wood substrate was much stronger than that of CPF. It is also noted that the elongation at break for both samples is about $1 \%$.

The ability of lignin phenol formaldehyde resin to bear additional loads before adhesive failure is attributable to the presence of lignin and phenol. In addition, the increased probability of strong bonds forming between the adhesive and wood substrate is facilitated by the structural similarity between lignin and phenol.

Table 3 shows the kinematics viscosity of LPF and CPF resins. The data indicate that LPF resin consistently generated lower values compared to CPF resin after being stored 


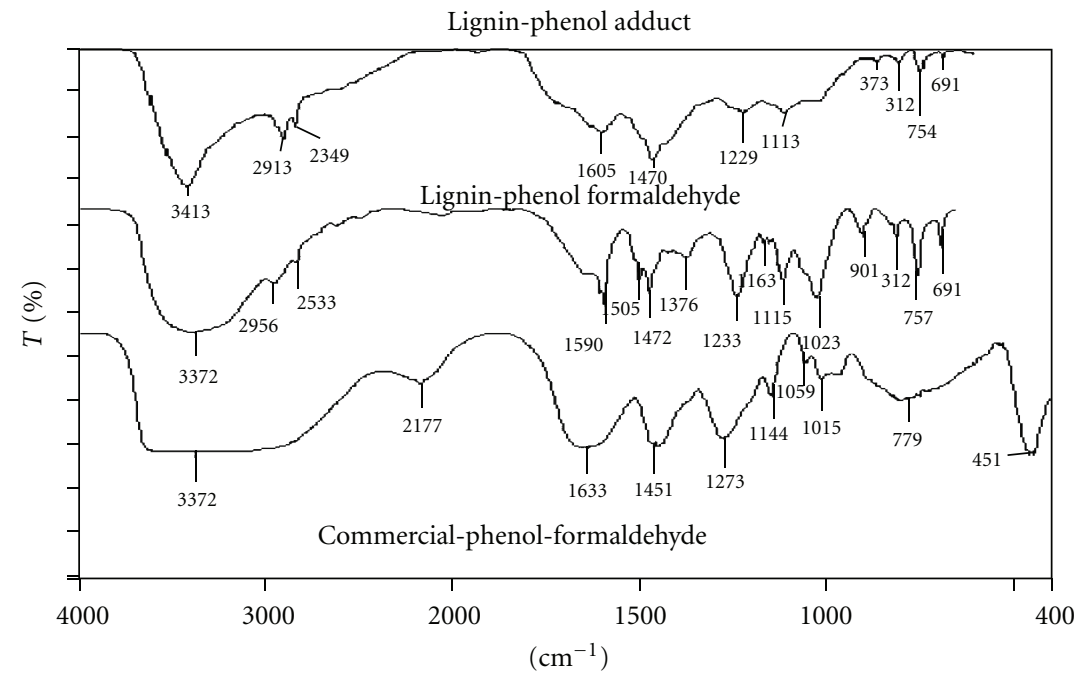

FIGURE 8: Comparison of IR spectra of lignin-phenol adduct, LPF and CPF resins.

TABLE 3: Results for viscosity test for LPF and CPF resins at different storage times.

\begin{tabular}{lcccc}
\hline \multirow{2}{*}{ Days } & \multicolumn{2}{c}{ LPF resins $(\mathrm{cSt})$} & \multicolumn{2}{c}{ CPF resins $(\mathrm{cSt})$} \\
& $25^{\circ} \mathrm{C}$ & $29^{\circ} \mathrm{C}$ & $25^{\circ} \mathrm{C}$ & $29^{\circ} \mathrm{C}$ \\
\hline 7 & 0.9656 & 0.8204 & 6.1781 & 5.7156 \\
14 & 0.9908 & 0.8612 & 9.9864 & 8.6264 \\
21 & 0.9746 & 0.8756 & 9.9884 & 9.1148 \\
\hline
\end{tabular}

for three weeks. The results also indicate that the kinematics viscosity for both resins increased with the elapse of time. Overall, the densities of LPF and CPF were $1.088 \mathrm{~g} / \mathrm{cm}^{3}$ and $1.196 \mathrm{~g} / \mathrm{cm}^{3}$, respectively. Since increase in viscosity is directly proportional to its density, it is not surprising that the CPF resin generated higher viscosity values as this resin has a higher density than LPF. However, high density will hinder resin movement and cause resin to freeze rapidly when exposed to air [52]. The lower viscosity of the LPF resin is attributable to the abundant presence of both aliphatic and aromatic hydroxyl groups in lignin. This consequently increases the ionization of the phenolic hydroxyl group in LPF thus increasing intermolecular ionic repulsion among molecules. The existence of these forces between the molecules therefore accounts for the lower viscosity of the LPF resin when compared to the CPF resin [53].

Apart from this, different temperatures generate different viscosity readings for both resins. At $29^{\circ} \mathrm{C}$, both resins share a lower viscosity reading compared to that at $25^{\circ} \mathrm{C}$. This is because viscosity decreases as temperature increases since the cohesive force between fluid molecules decreases as kinetic force increases [54]. As the tendency of resin to become viscous hinders the resin handling process on the substrate, especially on plywood $[55,56]$, the low kinematics viscosity of LPF resin is a preferable advantage as this would confer the resin a longer shelf life or storage time.
Pizzi [57] developed a promising technology based on premethylolated lignin in the presence of small amounts of a synthetic phenol-formaldehyde (PF) resin and polymeric 4,4-diphenyl methane diisocyanate (PMDI). The proportion of premethylolated lignin used is $65 \mathrm{wt} \%$ of the total adhesive, the balance being made up of $10-15 \%$ PF resin and of $20-25 \%$ PMDI. This adhesive presses at very fast speed, well within the fastest range used today industrially, contains a high proportion of lignin, and yields exterior grade boards. More recently, mixed wood panel adhesive formulations for interior-grade applications were developed using glyoxalated organosolv lignin. Glyoxal, in opposition to formaldehyde, is a nontoxic, nonvolatile aldehyde [58, 59]. However, the glyoxalated lignin by itself gave relatively low wood-joint strength, and it cannot be used alone as wood adhesive unless it can be cross-linked further. Thus, adhesive formulations based on glyoxylated organosolv lignin and mimosa tannin mixtures were prepared, and the rigidity of bonded wood joint in function of temperature was studied by thermomechanical analysis (TMA). The internal bond (IB) strength of a panel is a direct measure of the performance of the adhesive. Two different formulations prepared with miscanthus organosolv lignin and mimosa tannins were analyzed, and the results are given in the Table 4 . From this table, it can be seen that glyoxalated lignin/tannin 50/50 formulation does not satisfy the IB strength results required ( ${ }^{\ddagger} 0.35 \mathrm{MPa}$ ) but is slightly lower. On the basis of the known reactivity of polyflavonoid tannins with glyoxal, it was considered the addition of a further amount of tannin in the glue mix. Thus, glyoxalated lignin/tannin 60/40 formulation gives a good result and satisfies the relevant requirements of standard specifications for interior type wood particleboard [58].

Environment-friendly, nontoxic polymeric materials of natural origin constitute as much as $94 \%$ of the total panel binder formulation. The wood panel itself is then constituted of $99.5 \%$ natural materials. The $0.5 \%$ nonnatural material is composed of glyoxal, a nontoxic and nonvolatile aldehyde. 
TABLE 4: Results of wood particleboard bonded with glyoxalated organosolv lignin-mimosa tannin formulation [58].

\begin{tabular}{lcccc}
\hline Formulation & $\begin{array}{c}\text { Press time } \\
(\mathrm{mn})\end{array}$ & Temperature & $\begin{array}{c}\text { Density } \\
\left(\mathrm{kg} / \mathrm{m}^{3}\right)\end{array}$ & $\begin{array}{c}\mathrm{IB} / \mathrm{mm}^{2}= \\
\mathrm{Mpa}\end{array}$ \\
\hline $\begin{array}{l}\text { Lignin }(50 \%) \\
+\operatorname{tannin}\end{array}$ & $7.5 \mathrm{~min}$ & $195^{\circ} \mathrm{C}$ & 695 & $0.33 \pm 0.02$ \\
$\begin{array}{l}(50 \%) \\
\begin{array}{l}\text { Lignin }(40 \%) \\
+ \text { tannin }\end{array}\end{array}$ & $7.5 \mathrm{~min}$ & $195^{\circ} \mathrm{C}$ & 696 & $0.41 \pm 0.05$ \\
$(60 \%)$ & & & & \\
\hline
\end{tabular}

The resulting panels present an effective zero formaldehyde emission when tested by the dessicator method [60].

4.3. Ecofriendly Corrosion Inhibitors. Corrosion is an electrochemical process that takes place at the surface of a metal substrate when exposed to the atmosphere and other corrosive environment, causing the metal to deteriorate. In many industries, the need to use constructional materials safely, but cost-effectively, is a primary consideration, and thus the use of inhibitors is the most practical method to protect metals against corrosion. As environmental constraints continue to limit the use of many types of corrosion inhibitors, lignin presents a green alternative to using synthetic organic corrosion inhibitors that are mostly expensive and toxic. Lignin terpolymer that has been obtained by grafting copolymerisation of both dimethyl diallyl ammonium chloride and acrylamide onto lignin (from straw black liquor) recorded an inhibition of $95 \%$ against the corrosion of mild steel in $10 \% \mathrm{HCl}$ [61]. Alternatively, electropolymerization of lignosulfonates from the Russian pulp and paper factories in brine solution was found to reduce the corrosion rate of carbon steel by more than three times [62]. In addition, our studies have shown that soda and kraft lignin from the empty fruit bunch of palm oil was an excellent corrosion inhibitor of mild steel in $\mathrm{NaCl}$ at alkaline $\mathrm{pH}$ that was evaluated via electrochemical and weight-loss techniques. The adsorption mechanism of these lignins at the metal surface could have proceeded as follows: (1) electrostatic interaction between the charged metal, and the charged lignin molecules, (2) interaction of electrons pairs of the functional groups $(-\mathrm{OH}$, $\mathrm{COOH}$, etc.) in the lignin molecule with the metal surface, (3) interaction of $\pi$-electrons within the lignin molecule with the metal and (4) combination of (1) and (3). Alternatively as observed from the XRD, FTIR, and SEM results, lignin acts as a rust converter by transforming the rust components into ferric-lignin complexes, thus forming a protective layer that hinders further corrosion processes.

\section{Conclusion}

Lignin represents the second most abundant natural polymeric material on earth and is still currently underutilized. Large amounts of lignin are expected to be produced in future biorefineries as a by-product of biofuel production which is stimulating new emerging applications, principally as sustainable alternatives to nonrenewable products such as polyurethanes, thermoplastic polymers, epoxy and phenolic resins, as well as corrosion inhibitors. However, all the researches currently developed in these fields are carried out at the laboratory scale. Thus, the ability of organosolv lignins to provoke significant impact as a substitute for polymeric materials depends on its availability in industrial quantities.

\section{Acknowledgments}

The authors wish to thank the French Embassy in Kuala Lumpur for financial support. N. Brosse acknowledges the financial support of the CPER 2007-2013 "Structuration du Pôle de Compétitivité Fibres Grand'Est” (Competitiveness Fibre Cluster). The authors also gratefully acknowledge the financial support from Universiti Sains Malaysia, "Lignocellulosic Research Group" through Research University Grant scheme (1001/PKIMIA/854002).

\section{References}

[1] P. Kumar, D. M. Barrett, M. J. Delwiche, and P. Stroeve, "Methods for pretreatment of lignocellulosic biomass for efficient hydrolysis and biofuel production," Industrial and Engineering Chemistry Research, vol. 48, no. 8, pp. 3713-3729, 2009.

[2] X. Pan, J. F. Kadla, K. Ehara, N. Gilkes, and J. N. Saddler, "Organosolv ethanol lignin from hybrid poplar as a radical scavenger: relationship between lignin structure, extraction conditions, and antioxidant activity," Journal of Agricultural and Food Chemistry, vol. 54, no. 16, pp. 5806-5813, 2006.

[3] X. Pan, X. Zhang, H. D. J. Gregg, and J. N. Saddler, "Enhanced enzymatic hydrolysis of steam-exploded Douglas fir wood by alkali-oxygen post-treatment," Applied Biochemistry and Biotechnology, vol. 115, no. 1-3, pp. 1103-1114, 2004.

[4] X. Pan, D. Xie, R. W. Yu, D. Lam, and J. N. Saddler, "Pretreatment of lodgepole pine killed by mountain pine beetle using the ethanol organosolv process: fractionation and process optimization," Industrial and Engineering Chemistry Research, vol. 46, no. 8, pp. 2609-2617, 2007.

[5] N. Brosse, P. Sannigrahi, and A. Ragauskas, "Pretreatment of miscanthus $\mathrm{x}$ giganteus using the ethanol organosolv process for ethanol production," Industrial and Engineering Chemistry Research, vol. 48, no. 18, pp. 8328-8334, 2009.

[6] N. Brosse, R. El Hage, P. Sannigrahi, and A. Ragauskas, "Dilute sulphuric acid and ethanol organosolv pretreatment of miscanthus $x$ giganteus," Cellulose Chemistry and Technology, vol. 44, no. 1-3, pp. 71-78, 2010.

[7] G. Garrote, H. Domínguez, and J. C. Parajó, "Interpretation of deacetylation and hemicellulose hydrolysis during hydrothermal treatments on the basis of the severity factor," Process Biochemistry, vol. 37, no. 10, pp. 1067-1073, 2002.

[8] S. S. Tan, D. Y. Li, Z. Q. Jiang, Y. P. Zhu, B. Shi, and L.T. Li, "Production of xylobiose from the autohydrolysis explosion liquor of corncob using Thermotoga maritima xylanase B (XynB) immobilized on nickel-chelated Eupergit C," Bioresource Technology, vol. 99, no. 1, pp. 200-204, 2008.

[9] R. Vegas, J. L. Alonso, H. Domínguez, and J. C. Parajó, "Processing of rice husk autohydrolysis liquors for obtaining food ingredients," Journal of Agricultural and Food Chemistry, vol. 52, no. 24, pp. 7311-7317, 2004. 
[10] N. Brosse, P. Lan, P. Sannigrahi, and A. Ragauskas, "Evaluation of grape stalks as a bioresource," Industrial Crops and Products, vol. 33, no. 1, pp. 200-204, 2011.

[11] A. J. Ragauskas, C. K. Williams, B. H. Davison et al., "The path forward for biofuels and biomaterials," Science, vol. 311, no. 5760, pp. 484-489, 2006.

[12] W. G. Glasser and R. S. Wright, "Steam-assisted biomass fractionation. II. Fractionation behavior of various biomass resources," Biomass and Bioenergy, vol. 14, no. 3, pp. 219-235, 1998.

[13] I. Ballesteros, M. J. Negro, J. M. Oliva, A. Cabañas, P. Manzanares, and M. Ballesteros, "Ethanol production from steamexplosion pretreated wheat straw," Applied Biochemistry and Biotechnology, vol. 129-132, no. 1-3, pp. 496-508, 2006.

[14] I. Ballesteros, M. J. Negro, J. M. Oliva, A. Cabañas, P. Manzanares, and M. Ballesteros, "Ethanol production from steamexplosion pretreated wheat straw," Applied Biochemistry and Biotechnology, vol. 130, no. 1-3, pp. 496-508, 2006.

[15] J. M. Lavoie, E. Capek-Menard, H. Gauvin, and E. Chornet, "Production of pulp from Salix viminalis energy crops using the FIRSST process," Biomass and Bioenergy, vol. 34, no. 9, pp. 1342-1347, 2010.

[16] J. M. Lavoie, E. Capek-Menard, H. Gauvin, and E. Chornet, "Production of pulp from Salix viminalis energy crops using the FIRSST process," Bioresource Technology, vol. 101, no. 13, pp. 4940-4946, 2010.

[17] T. Josefsson, H. Lennholm, and G. Gellerstedt, "Steam explosion of aspen wood. Characterisation of reaction products," Holzforschung, vol. 56, no. 3, pp. 289-297, 2002.

[18] N. Park, H. Kim, B. Koo, H. Yeo, and I. Choi, "Organosolv pretreatment with various catalysts for enhancing enzymatic hydrolysis of pitch pine (Pinus rigida)," Bioresource Technology, vol. 101, no. 18, pp. 7046-7053, 2010.

[19] R. El Hage, L. Chrusciel, L. Desharnais, and N. Brosse, "Effect of autohydrolysis of Miscanthus x giganteus on lignin structure and organosolv delignification," Bioresource Technology, vol. 101, no. 23, pp. 9321-9329, 2010.

[20] L. Jiménez, I. Pérez, J. C. García, and A. Rodríguez, "Influence of process variables in the ethanol pulping of olive tree trimmings," Bioresource Technology, vol. 78, no. 1, pp. 63-69, 2001.

[21] D. Sidiras and E. Koukios, "Simulation of acid-catalysed organosolv fractionation of wheat straw," Bioresource Technology, vol. 94, no. 1, pp. 91-98, 2004.

[22] I. Akamatsu, M. B. Husin, H. Kamishima, and A. H. Hassan, "Industrial utilization of oil palm (Elaeis guneensis) by-products. 1. Kraft-anthraquinone pulping of oil palm empty fruit bunches," Cellulose Chemistry and Technology, vol. 21, pp. 6775, 1987.

[23] K. C. Khoo and T. W. Lee, "Pulp and paper from oil palm," APPITA Journal, vol. 44, no. 6, pp. 385-388, 1991.

[24] F. Zhinan and A. Raimo, "Soda-AQ pulping of reed canary grass," Industrial Crops and Products, vol. 14, no. 1, pp. 31-39, 2001.

[25] W. D. Wan Rosli, K. N. Law, Z. Zainuddin, and R. Asro, "Effect of pulping variables on the characteristics of oil-palm frondfiber," Bioresource Technology, vol. 93, no. 3, pp. 233-240, 2004.

[26] A. García, A. Toledano, L. Serrano et al., "Characterization of lignins obtained by selective precipitation," Separation and Purification Technology, vol. 68, no. 2, pp. 193-198, 2009.

[27] R. C. Sun and J. Tomkinson, "Fractional separation and physico-chemical analysis of lignins from the black liquor of oil palm trunk fibre pulping," Separation and Purification Technology, vol. 24, no. 3, pp. 529-539, 2001.
[28] M. N. Mohamad Ibrahim, S. B. Chuah, and W. D. Wan Rosli, "Characterization of lignin precipitated from the soda black liquor of oil palm empty fruit bunch fibers by various mineral acids," Asian Science, Technology and Society for Development, vol. 21, no. 1, pp. 57-68, 2004.

[29] G. Lissens, H. Klinke, W. Verstraete, B. Ahring, and A. B. Thomsen, "Wet oxidation pre-treatment of woody yard waste: parameter optimization and enzymatic digestibility for ethanol production," Journal of Chemical Technology and Biotechnology, vol. 79, no. 8, pp. 889-895, 2004.

[30] P. Oleskowicz-Popiel, P. Lisiecki, J. B. Holm-Nielsen, A. B. Thomsen, and M. H. Thomsen, "Ethanol production from maize silage as lignocellulosic biomass in anaerobically digested and wet-oxidized manure," Bioresource Technology, vol. 99, no. 13, pp. 5327-5334, 2008.

[31] T. H. Kim and Y. Y. Lee, "Pretreatment and fractionation of corn stover by ammonia recycle percolation process," Bioresource Technology, vol. 96, no. 18, pp. 2007-2013, 2005.

[32] F. S. Chakar and A. Ragauskas, "Review of current and future softwood kraft lignin process chemistry," Industrial Crops and Products, vol. 20, no. 2, pp. 131-141, 2004.

[33] R. Vanholme, K. Morreel, J. Ralph, and W. Boerjan, "Lignin engineering," Current Opinion in Plant Biology, vol. 11, no. 3, pp. 278-285, 2008.

[34] J. H. Banoub and M. Delmas, "Structural elucidation of the wheat straw lignin polymer by atmospheric pressure chemical ionization tandem mass spectrometry and matrix-assisted laser desorption/ionization time-of-flight mass spectrometry," Journal of Mass Spectrometry, vol. 38, no. 8, pp. 900-903, 2003.

[35] T. J. McDonough, "The chemistry of organosolv delignification," Tappi Journal, vol. 76, no. 8, pp. 186-193, 1993.

[36] R. El Hage, N. Brosse, L. Chrusciel, C. Sanchez, P. Sannigrahi, and A. Ragauskas, "Characterization of milled wood lignin and ethanol organosolv lignin from miscanthus," Polymer Degradation and Stability, vol. 94, no. 10, pp. 1632-1638, 2009.

[37] R. El Hage, N. Brosse, P. Sannigrahi, and A. Ragauskas, "Effects of process severity on the chemical structure of Miscanthus ethanol organosolv lignin," Polymer Degradation and Stability, vol. 95, no. 6, pp. 997-1003, 2010.

[38] M. P. Froass, A. J. Ragauskas, and J. Jiang, "Nuclear magnetic resonance studies. 4. Analysis of residual lignin after kraft pulping," Industrial and Engineering Chemistry Research, vol. 37, no. 8, pp. 3388-3394, 1998.

[39] B. B. Hallac, Y. Pu, and A. J. Ragauskas, "Chemical transformations of Buddleja davidiilignin during ethanol organosolv pretreatment," Energy and Fuels, vol. 24, no. 4, pp. 2723-2732, 2010.

[40] P. Mousavioun, W. Doherty, and G. George, “Thermal stability and miscibility of poly(hydroxybutyrate) and soda lignin blends," Industrial Crops and Products, vol. 32, no. 3, pp. 656661, 2010.

[41] R. Pucciariello, C. Bonini, M. D’Auria, V. Villani, G. Giammarino, and G. Gorrasi, "Polymer blends of steam-explosion lignin and poly(E-caprolactone) by high-energy ball milling," Journal of Applied Polymer Science, vol. 109, no. 1, pp. 309-313, 2008.

[42] D. Feldman, D. Banu, R. Manley, and H. Zhu, "Highly filled blends of a vinylic copolymer with plasticized lignin: thermal and mechanical properties," Journal of Applied Polymer Science, vol. 89, no. 7, pp. 2000-2010, 2003.

[43] S. Kubo and J. F. Kadla, "Poly(ethylene oxide)/organosolv lignin blends: relationship between thermal properties, chemical structure, and blend behavior," Macromolecules, vol. 37, no. 18, pp. 6904-6911, 2004. 
[44] J. H. Lora and W. G. Glasser, "Recent industrial applications of lignin: a sustainable alternative to nonrenewable materials," Journal of Polymers and the Environment, vol. 10, no. 1-2, pp. 39-47, 2002.

[45] L. Wu and W. G. Glasser, "Engineering plastics from lignin. I. Synthesis of hydroxypropyl lignin," Journal of Applied Polymer Science, vol. 29, no. 4, pp. 1111-1123, 1984.

[46] W. Glasser, C. Barnett, T. G. Rials, and V. P. Saraf, "Engineering plastics from lignin II. Characterization of hydroxyalkyl lignin derivatives," Journal of Applied Polymer Science, vol. 29, no. 5, pp. 1815-1830, 1984.

[47] M. R. Roger, "Kimia kayu padu," in Perpustakaan UPM Bintulu, M. R. Roger, Ed., vol. 6, pp. 235-246, Dewan Bahasa and Pustaka Publisher, Kuala Lumpur, Malaysia, 2nd edition, 1994, (Translated by Suhaimi Muhammed and Halimahton Haji Mansor).

[48] A. K. Muzaffar, M. A. Sayed, and P. M. Ved, "Development and characterization of a wood adhesive using bagasse lignin," International Journal of Adhesion and Adhesives, vol. 24, no. 6, pp. 485-493, 2004.

[49] V. P. Alphonsus, Adhesion and Adhesives Technology, An Introduction, Hanser Publisher, New York, NY, USA, 1997.

[50] P. Y. Bruice, Organic Chemistry, Pearson Education International, New Jersey, NJ, USA, 3rd edition, 2001.

[51] M. A. Khan, S. M. Ashraf, and V. P. Malhotra, "Eucalyptus bark lignin substituted phenol formaldehyde adhesives: a study on optimization of reaction parameters and characterization," Journal of Applied Polymer Science, vol. 92, no. 6, pp. 35143523, 2004.

[52] G. T. Tsoumis, Science and Technology of Wood: Structure, Properties and Utilization, Van Nostrand Reinhold, New York, NY, USA, 1991.

[53] R. A. Haupt and T. Sellers Jr., "Characterizations of phenolformaldehyde resol resins," Industrial \& Engineering Chemistry Research, vol. 33, no. 3, pp. 693-697, 1994.

[54] L. Robert, Polymer Chemistry, Revised Edition-A Teaching Package for Pre-Collage Teachers, National Science Teachers Association, Wilson Boulevard, 1995.

[55] A. K. Shawkataly and H. Rokiah, Komposit Panel Berasaskan Sumber Kayu, Penerbit Universiti Sains Malaysia, Pulau Pinang, Malaysia, 2004.

[56] S. J. Terry, Plywood and Adhesive Technology, Marcel Deckker, New York, NY, USA, 1985.

[57] A. Pizzi, "Recent developments in eco-efficient bio-based adhesives for wood bonding: opportunities and issues," Journal of Adhesion Science and Technology, vol. 20, no. 8, pp. 829-846, 2006.

[58] R. El Hage, N. Brosse, P. Navarrete, and A. Pizzi, "Extraction, characterization and utilization of Organosolv Miscanthus Lignin for the conception of Environmentally friendly mixed tannin/lignin wood resins," Journal of Adhesion Science and Technology. In press.

[59] H. R. Mansouri, P. Navarrete, A. Pizzi et al., "Synthetic-resinfree wood panel adhesives from mixed low molecular mass lignin and tannin," Journal of Adhesion Science and Technology, vol. 24, no. 8, pp. 1597-1610, 2010.

[60] A. Pizzi, J. Valenezuela, and C. Westermeyer, "Low formaldehyde emission, fast pressing, pine and pecan tannin adhesives for exterior particleboard," Holz als Roh- und Werkstoff, vol. 52, no. 5, pp. 311-315, 1994.

[61] Y. Ren, K. Zhang, G. Zhu, and X. Tan, "Lignin terpolymer for corrosion inhibition of mild steel in 10\% hydrochloric acid medium," Corrosion Science, vol. 50, no. 11, pp. 3147-3153, 2008.
[62] M. Y. Vagin, S. A. Trashin, and A. A. Karyakin, "Corrosion protection of steel by electropolymerized lignins," Electrochemistry Communications, vol. 8, no. 1, pp. 60-64, 2006. 

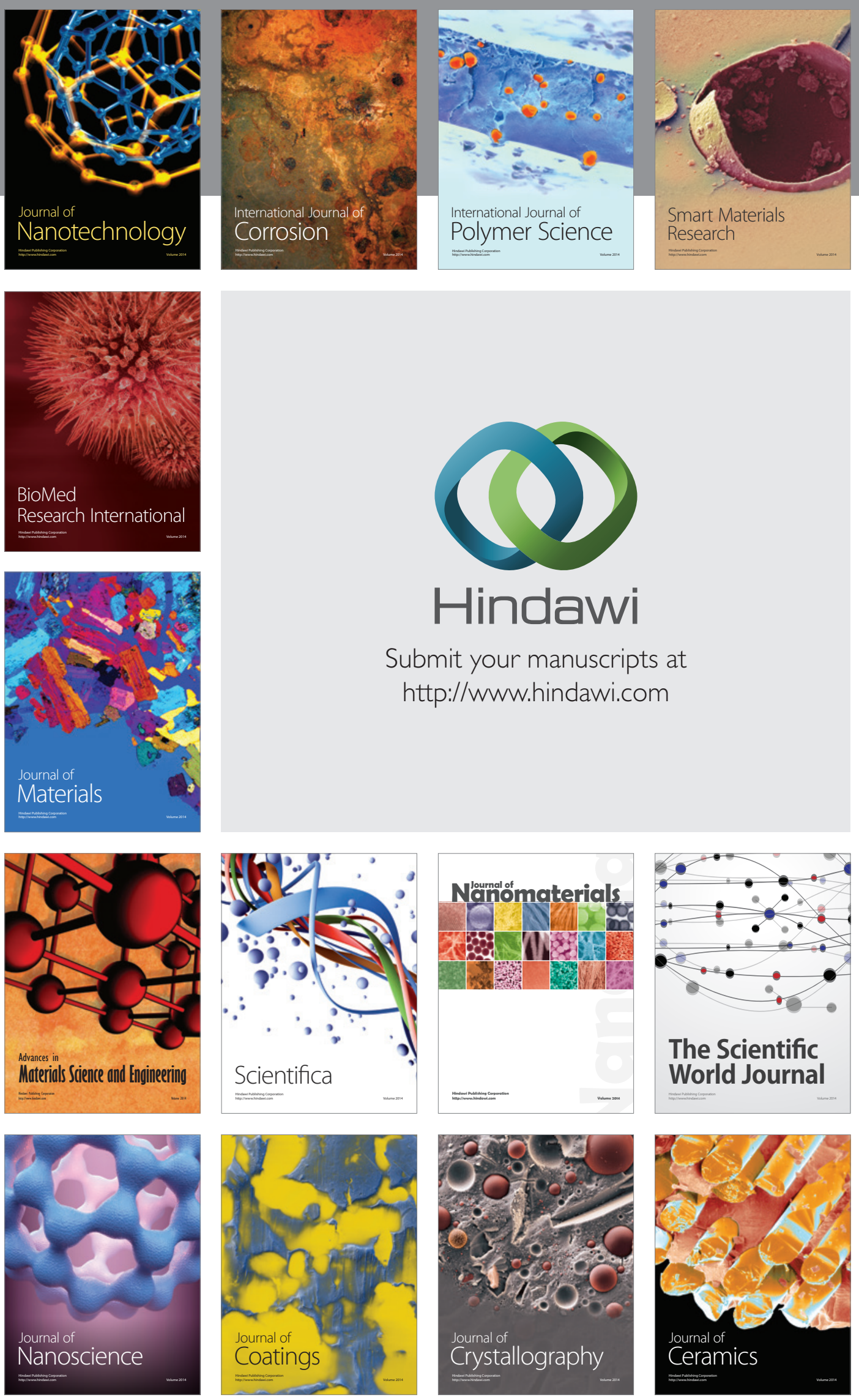

The Scientific World Journal

Submit your manuscripts at

http://www.hindawi.com

\section{World Journal}

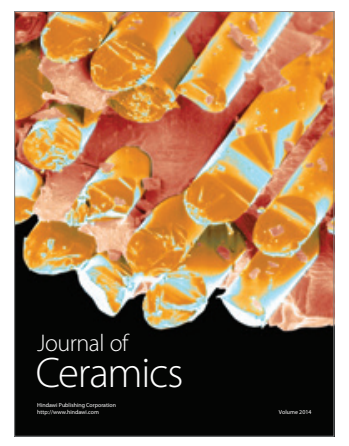

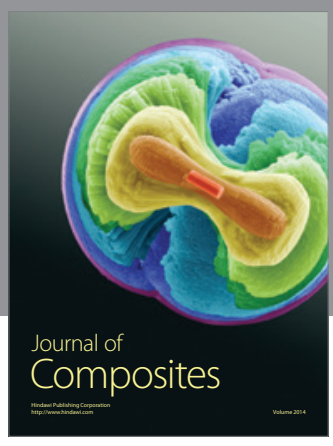
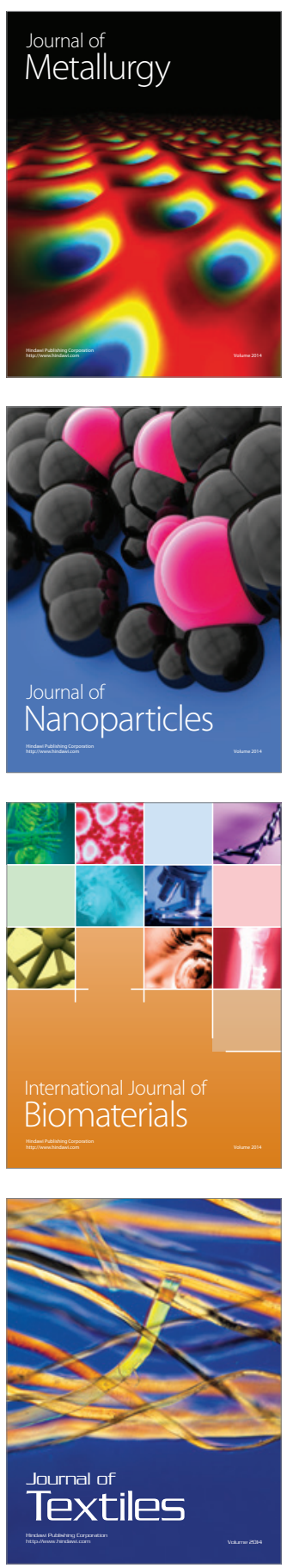